\title{
Structure and service safety of deep disposal landfills - case study
}

\author{
Dariusz Bajno ${ }^{1 *}$, Agnieszka Grzybowska ${ }^{1}$, Rafał Tews $^{1}$ and Lukasz Bednarz ${ }^{2}$ \\ ${ }^{1}$ University of Science and Technology, Faculty of Civil and Environmental Engineering and \\ Architecture, Department of Building Structures, Poland \\ ${ }^{2}$ Wroclaw University of Science and Technology, Faculty of Civil Engineering, Poland
}

\begin{abstract}
This paper discusses issues related to operation of environment protection facilities in immediate vicinity of natural water reservoirs, including fresh water reservoirs, located above and below ground. The subject of this study is a municipal solid waste landfill located in southwestern Poland and its related facilities included in the technological processes of waste disposal, treatment, and recycling. The paper briefly discusses the construction process stage and the first stage of operation of the studied facility in respect of their future impact on the environment. At the present time, waste is used to obtain landfill gas for electricity generation and materials to be reincorporated or disposed of, i.e. construction debris (brick, concrete), structural steel, firewood, and plastics. The range of topics presented in the paper is in accord with the sustainable development tendency and the paper specifically focuses on potential hazards arising from presence and operation of facilities of this type (built at a time when environment protection regulations were less restrictive as to their location). Continuity and effectiveness of insulation membranes of landfills are important inasmuch as once such landfills are filled with waste and then closed and reclaimed at the final stage, it will be extremely difficult to identify sites of potential leaks of basins, whose expected lifespan is several decades or a few hundred years. If such leaks are found within this period, it will be necessary to remove reclamation layers and strongly thickened waste in order to reach them [12]. Then, new damage resulting from operation of heavy equipment might occur. Therefore, apart from standard protection solutions of landfills, additional warning systems should be applied for maximum elimination of environmental pollution hazards, the range of which can be supralocal or even supraregional. Such systems should precisely indicate the location of probable places of hazards. It is not about damage to facilities, including cells, but about safety of their surroundings. Due to the vastness of the topic referred to herein, the paper has been narrowed down to include only one issue, i.e. tightness of cells intended for non-hazardous and non-inert waste.
\end{abstract}

\footnotetext{
* Corresponding author: dariusz.bajno@utp.edu.pl
} 


\section{Introduction}

The subject of this paper is municipal solid waste landfills that are representatives of the group of facilities serving to protect our environment, and specifically a deep disposal system for non-hazardous waste which has been operated since 1996 [2, 3, 4, 5] with a surface of cells of approx. 25 ha (within their crest) and a volume expected to be approx. $2.4 \div 5.0$ million $\mathrm{Mg}$, which will depend on waste thickening capacities $\sim 1.2 \div 2.5 \mathrm{Mg} / \mathrm{m}^{3}$. Closed workings, from which marl was obtained for a former local cement mill, were used there to make the cells. In that period, the applicable Polish regulations were somewhat tolerant when it came to location of such facilities.

Only residues of classified and registered waste, selected from recycling lines and segregated at source, is delivered to the basins. It is disposed of in layers of thickness not exceeding $2.0 \mathrm{~m}$ and separated with spacing process material of $0.2-0.3 \mathrm{~m}$ in thickness. The basins are fitted with leachate systems for discharging liquid waste fermentation products into the leachate tank and then to the sewage treatment plant. Clean water drainage is arranged under the insulating layers of the cells to adjust the level of water dripping in gaps of cracked calcareous rock constituting the base of the above-mentioned facilities and monitoring the cleanliness of such water.

The entire deposit is degassed. Deposit gas is collected in sumps and then fed with suction pipes to the station equipped with a unit, where combustion energy is converted into electricity. Landfills are built, operated and monitored on the basis of relevant building and integrated permits. Modernisation of such facilities is extremely difficult due to processing units supporting the landfill which are buried deep under the hundreds of tonnes of waste (including under the basins).

The history of waste landfills having been built in the post-WWII period suggests that these facilities were located wherever it had been convenient for agglomerations serviced thereby. An overwhelming majority of these were unsealed earth structures located in commonly accessible places, irrespective of geological structure of the terrain $[6,7,8,9,10]$.

Today, landfills for non-hazardous and non-inert waste are modern facilities continuously adapted to Polish and EU law being modified in this respect. They are equipped with a variety of plants that manage waste segregation and recycling as well as waste treatment and disposal in the last stage. It does not necessarily mean that such landfills cannot receive and periodically collect hazardous waste.

The authors of the paper have not attempted to evaluate suitability or effectiveness of operation of such facilities; the same is true for the processes of waste segregation and treatment taking place there. The paper focuses on issues of maintaining operational safety of landfills in relation to their immediate as well as the more distant surroundings, and specifically in relation to fresh water reservoirs and river valleys located nearby. In this day and age such placement of a landfill is impossible. As provided for in regulation [1], Section 2.1, hazardous, non-hazardous, and non-inert waste landfills cannot be located e.g. in protection areas of underground water reservoirs, river valleys, areas exposed to flood risk, etc. Furthermore, as of today, disposal of waste into landfill cells has been substantially reduced, while disposal of biodegradable waste has been practically eradicated.

Heavy equipment, represented mainly by compactors, is used for waste compaction in order to reduce the filling of landfill cells. It includes machines characterised by their large weight, reaching as much as up to 35 tonnes (Fig. 1a), and high unit pressure. Their task is to compact waste to the greatest extent possible in order to prolong cell life. The basic parameter by which compactors are characterised is their ground contact pressure. It is exerted by steel ride-on rollers equipped with pyramid-shaped spikes for maximum waste compaction and fragmentation. The shape of the spikes makes it possible to achieve 
maximum ground contact pressure. Spike tracks left by the front drums of the compactor do not overlap with spike tracks left by the rear drums. After $3 \div 5$ runs of the compactor, the level of compaction is expected to increase from $350 \mathrm{~kg} / \mathrm{m}^{3}$ up to $1200 \div 2500 \mathrm{~kg} / \mathrm{m}^{3}$ (Fig. $1 \mathrm{a}, \mathrm{b})$.

a)

b)
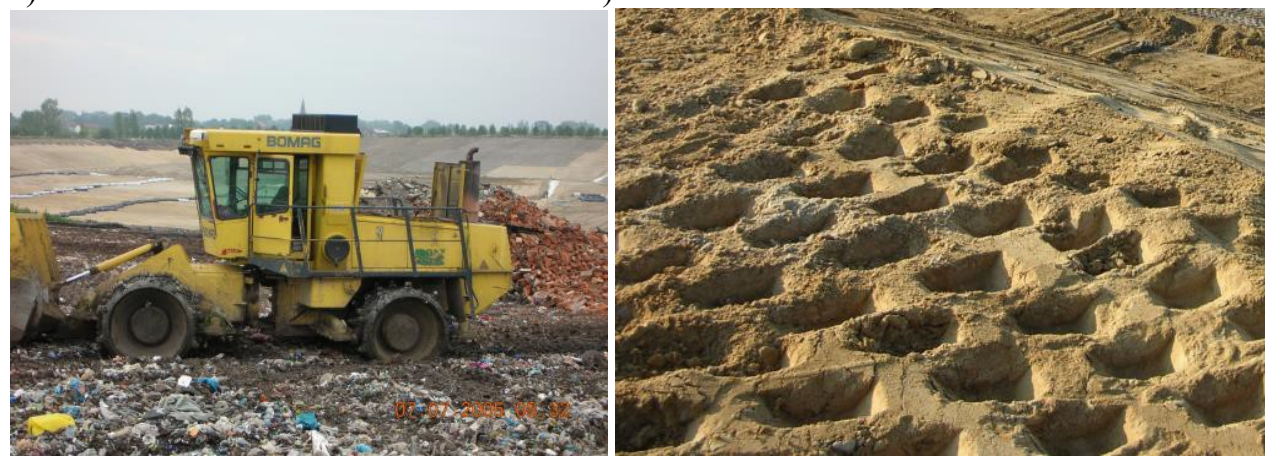

Fig. 1. A typical municipal solid waste landfill: compactor, spreading and compacting waste, b) tracks of pyramid-shaped spikes of the compactor drum (photograph by: the author)

In addition, spikes on compactors can become one of the causes of damaged sealing layers in landfill basins at the initial stages of their lifecycle, even when protection layers are used. Detection and location of damage is hard and sometimes even virtually impossible because landfill sealing surfaces are so vast. Traditional environmental monitoring, including research into/the testing of: groundwater level and composition, surface water flow rate and composition, leachate water composition, landfill gas composition, precipitation, the course of landfill settlement as well as structure and mass of the landfilled waste can at times turn out to be insufficient to obtain reliable data from it that could evidence full tightness at the waste disposal basins. Another method of preventing environmental pollution is to control humidity of precipitation and maintain it on a relatively low level which will limit penetration of leachate through the protective barriers of the basins in the event they are damaged [14]. This method, however, does not ensure effective protection of the soil and water against contamination.

\section{The structure of waste disposal cells}

Proper completion of a building structure does not release its manager from the duty to monitor its technical condition [2], especially when it is related to operational safety of waste landfills - environment protection facilities that, if incorrectly operated and monitored, can become a danger to the environment. The analysis covered a non-hazardous non-inert waste landfill located on one of the largest fresh water reservoirs in Europe and simultaneously in the Odra river valley. Moreover, this structure is located within a floodplain struck by the flooding of 1997. At that time, one of the cells was already partially filled with municipal solid waste. 
a)

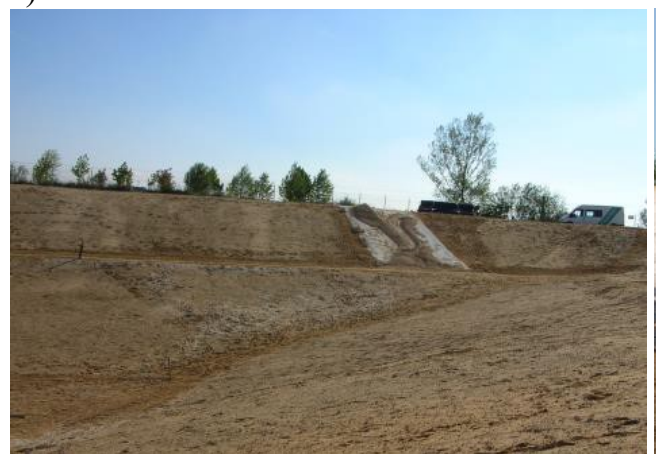

b)

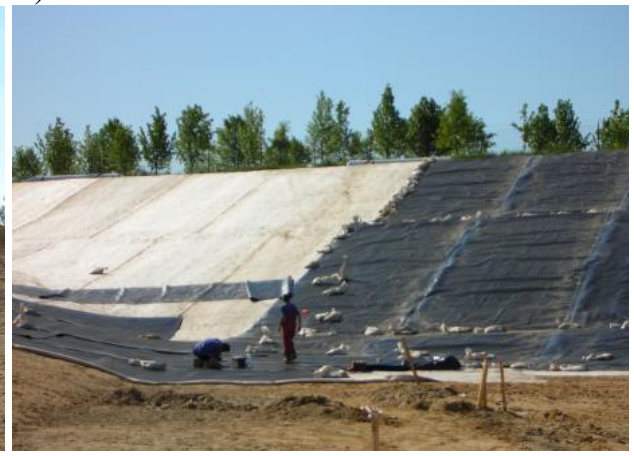

Fig. 2. The structure of the 2 nd cell at the municipal solid waste landfill: a) bottom layer of sand underneath the geomembrane, b) sealing layers (bentonite sealing and geomembrane) and the reinforcing layer (geotextile) (photograph by: the author)

The landfill disposal cells are typical earth structures reinforced with membranes, which apart from their intended role - may pose a real threat to the surroundings and environment. Therefore, at this construction stage, they should be carefully supervised by applying modern monitoring techniques capable of eliminating even the lowest probability of the threat. As it was mentioned above, they are earth structures constantly affected by climatic factors and exposed to effects of chemical substances contained in waste, mechanical loads from vehicles and pressure applied by hard objects. They can also be subjected to hydrostatic pressure of ground and infiltration water. These facilities, extensively built in the second half of the $20^{\text {th }}$ century on the ground level or deep below, were mainly intended for the disposal of mixed municipal solid waste, including waste with slow decomposition rate (plastics) and waste subject to fermentation processes (biowaste).

The landfill being the subject of this paper is equipped with:

- two cells for deep disposal of waste, with areas calculated at the level of their crest amounting to: 8.56 ha (No. 1) and 16.57 ha (No. 2), with total volume of approx. 2 million $\mathrm{m}^{3}$,

- bioenergy plant, active power $100 \div 450 \mathrm{KW}$,

- alternative fuel production plant,

- tunnel composting plant,

- pile composting plant for green waste,

- construction debris crushing and recovery line,

- warehouse for temporary storage of hazardous materials.

In Figures 2 and 3, the layered structure of disposal cells has been shown using an example of a cell commissioned in 1996 (Fig. 3a) and of a cell built in the 2000s (Fig. 2a,b and Fig. $3 \mathrm{~b}$ ), respectively. These two facilities, completed in two different periods, differ by just one reinforcing layer made from a geotextile. This safety measure was not used in the basin commissioned in 1996. 
a)

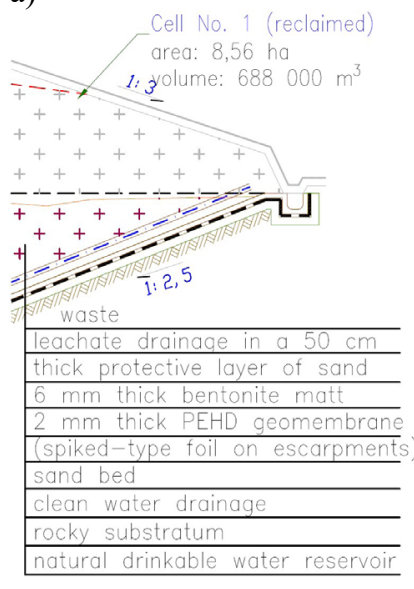

b)

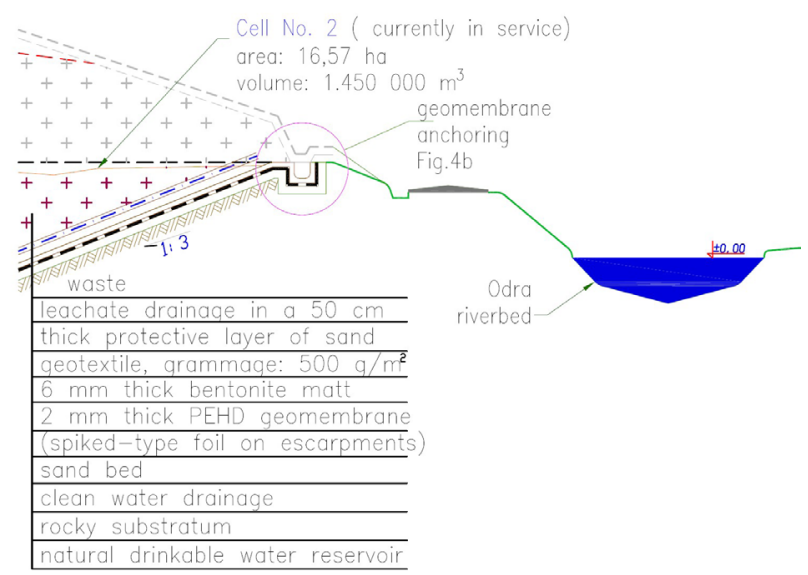

Fig. 3. Cross section through the basin of the cell: a) launched in 1996, b) currently in service (own work)

a)

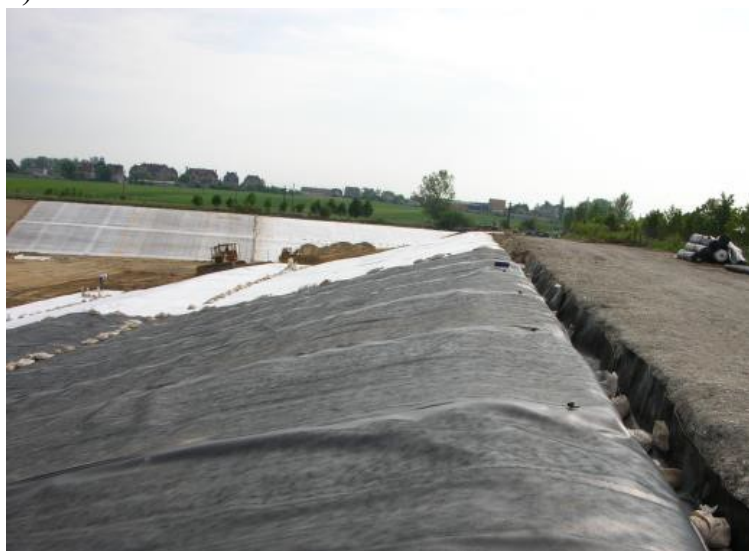

b)

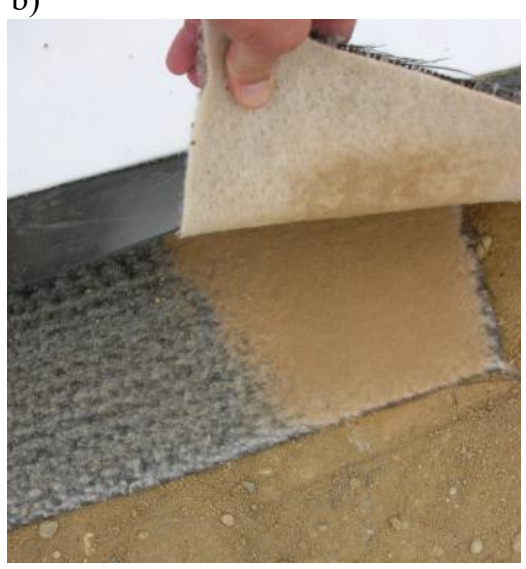

Fig. 4. The structure of the 2 nd cell at the municipal solid waste landfill: a) geomembrane anchoring on an escarpment, b) reinforcing layer (geotextile - white) and the sealing layers (geomembrane black, bentonite sealing - grey) (photograph by: the author).

\section{Securing the bottom and the escarpments}

A very crucial element that determines tightness of such an extensive surface of cell basins is welded joints of membrane strips and their correct placement on escarpments, including correct anchoring (Fig. 4a). The photograph below shows the process of joining a membrane by welding its edge (Fig. 5a) and the process of checking the tightness of such a joint (Fig. 5b) by measuring the pressure of air compressed to ca. $0.3 \mathrm{MPa}$ in the valve created between the welds. 
a)

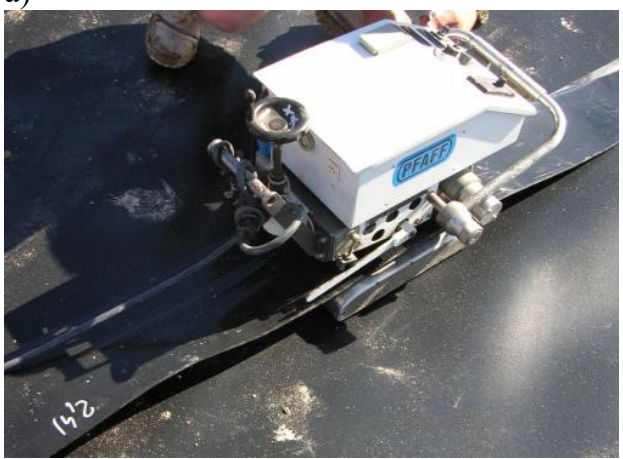

b)

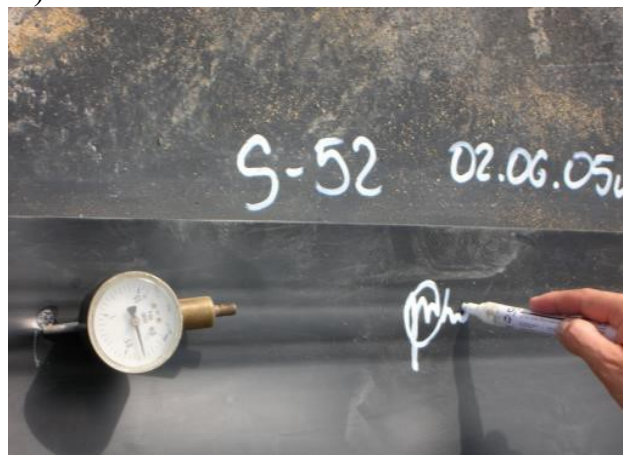

Fig. 5. Geomembrane installation: a) welding device making a joint, b) weld pressure testing (photograph by: the author)

a)

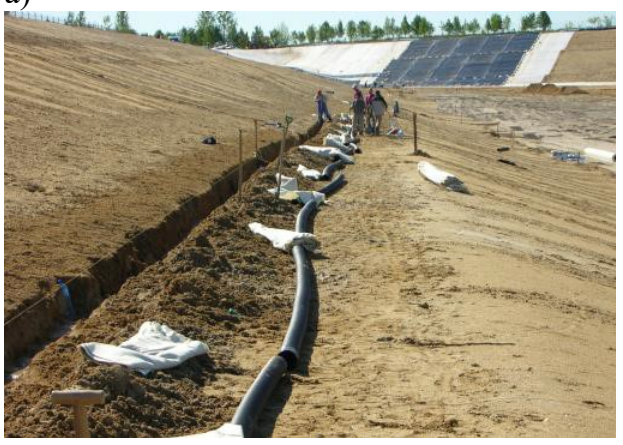

b)

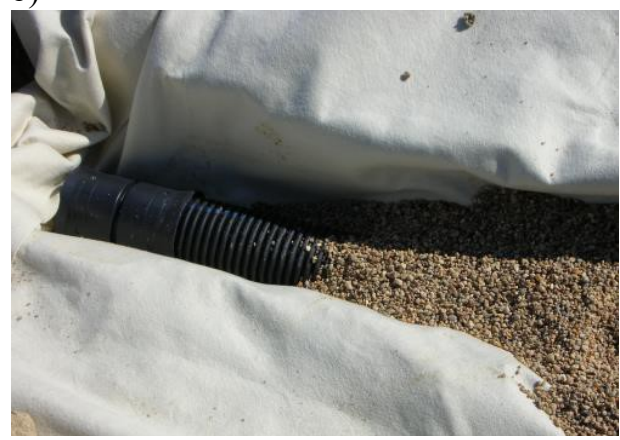

Fig. 6. Drainage of: a) clean water, b) leachates (photograph by: the author)

Each connection of membrane sections of this type should be inspected by authorised persons, and technical acceptance should be confirmed by the supervising inspector making an entry and signing the joints acceptance report, and placing his/her signature directly on/near the weld (Fig. 5b). The next major component of the basin seal system is the two drainages. The clean water drainage (Fig. 6a) regulates the water level just beneath the basin and is performing water monitoring tests by connection to piezometers. The leachate drainage (Fig. 6b) drains the landfill leachate to the leachate tank, and then pumps it to a water treatment plant.

\section{Tightness monitoring}

In case of facilities such as landfill cells, visual inspection and acceptance of concealed and covered-up works (including tests described in Section 3 - Fig. 5b above) are not capable of detecting each and every defect in sealing systems, which span across a few or even more than ten hectares. In spite of the fact that they have been equipped with subsurface drainage systems intended to detect if there is any environmental release of a leachate beyond the protective membrane, physical location of the place where such a leakage occurred is practically undetectable, even in cases where the basin is only slightly filled. Finding a leak alone does not solve the problem of safe operation of the facility and protecting its surroundings against contamination and degradation. While the second landfilling cell was being built, a decision to implement a then-pioneering solution, i.e. sensor monitoring, in Poland and Europe was made. The monitoring system was expected 
to detect increases in substratum damping and changes in the quality of clean waters arising from perforation or leaking membrane as well as to track them with an accuracy of $10 \div 15 \mathrm{~cm}$.

a)

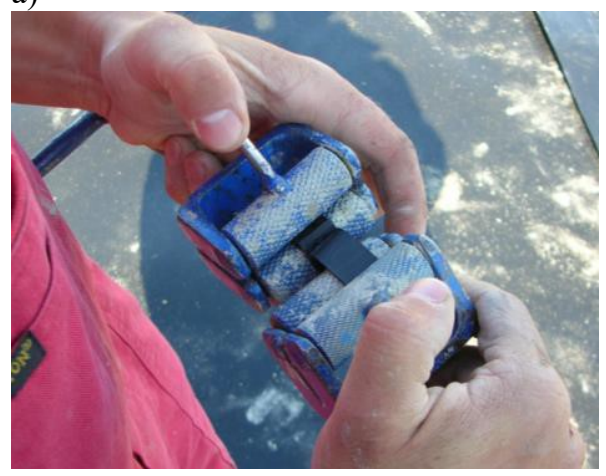

b)

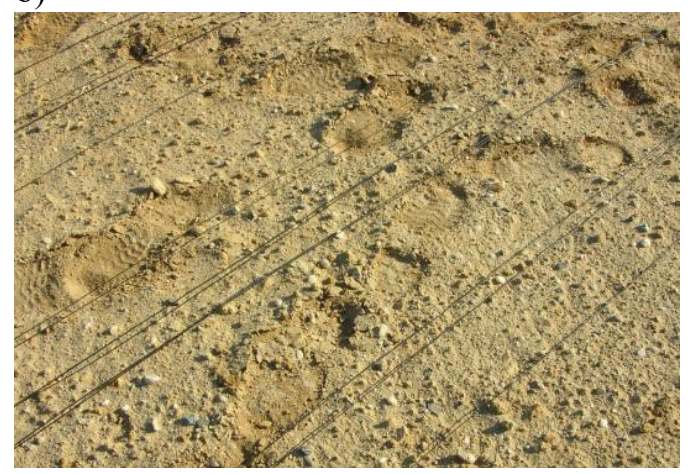

Fig. 7. Measures used to ensure tightness of the bottom and of the basin escarpments: a) geomembrane joints (welds) strength testing, b) sensor monitoring - wiring (photograph by: the author).

The sensor system monitoring the tightness of the bottom and of the basin escarpments DDS - was placed under the bentonite matt. Initially, a 5-year lifecycle had been assumed for this installation but it was ultimately extended to 20 years. This system employs a dense network of sensors electrically wired to a measuring device controlled by a PC equipped with a dedicated computer program. It can fully control the tightness of safety measures in landfills filled with materials that should never permeate into the ground or clean waters. Not all of the active landfills have such safety measures in place, which is particularly true for those manufactured in the second half of the previous century. The storage cell described in this paper was equipped with the system referred to here as a consequence of some reasonable thinking done by the person responsible for the investment project (2005), because such systems were neither designed nor manufactured at the time.

\section{Summary}

The paper elaborates on the issue of safe waste landfill operation. Environment protection facilities are not neutral to what surrounds them and they should have safety measures in place to eliminate their negative impact on natural environment to the maximum extent. This specifically applies to facilities located in the vicinity of underground drinkable water reservoirs and water reservoirs on the ground level. Contamination of water or ground can lead to an ecological disaster and the range of this disaster can even be supraregional, hence an unusually important task is assigned to systems that are monitoring all safety measures to which possible leaks of harmful substances as well as emission of gases and odours to the environment might be attributed. As practical experience has shown, it has not been possible to entirely eliminate such hazards. They may be encountered both at the stage of producing underlying layers of the structure and basin sealing (Fig. 8) and at the stage when the facility is being operated after commissioning (Fig. 9). The main cause of such situations is mechanical damage inflicted by heavy equipment moving within these facilities (Fig. 10). Furthermore, damage can also be caused by deformations relating to uneven settlement of the cell bottom and escarpment due to, e.g. cracking of the base or its heterogeneous structure and as a result of uneven displacement of waste in the cells. 
a)

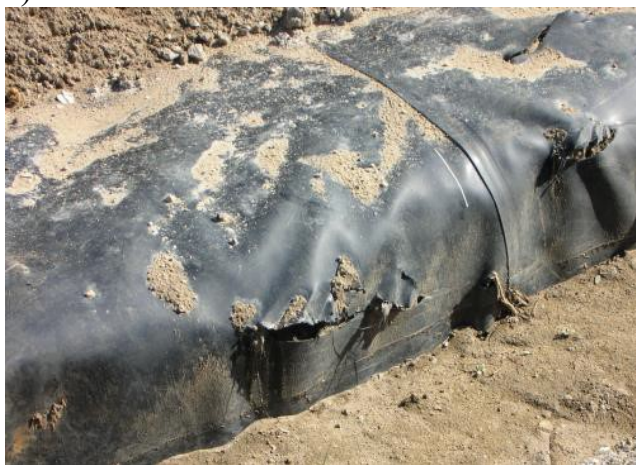

b)

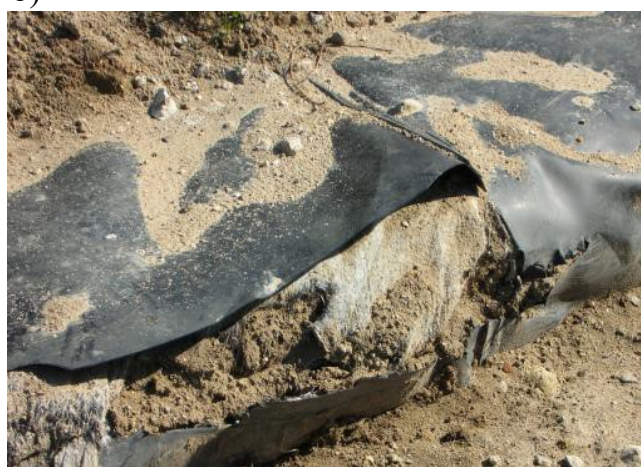

Fig. 8. Types of sealing damage done as early as during construction works - cut membranes (photograph by: the author).

The Digital Surveillance System (DSS) proved to be an additional, utterly effective plant in geomembrane tightness assessment referred to above. The System indicated leaks and leak locations as early as at the stage of cell construction and at the first stage of its operation. These were consequences of rather careless use of heavy equipment in earthworks (Fig. 10).

a)

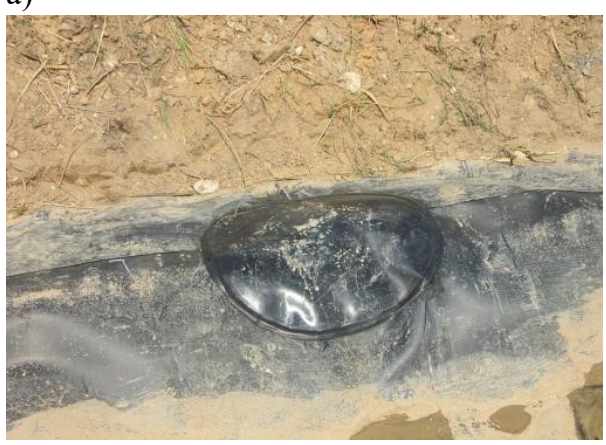

b)

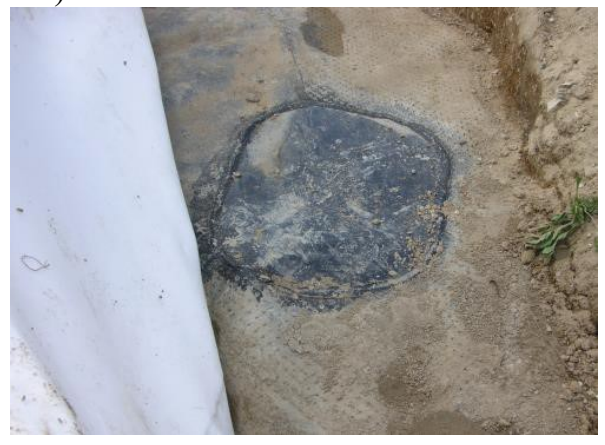

Fig. 9. Repair patches for damage done at the first stage of cell operation (photograph by: the author) 


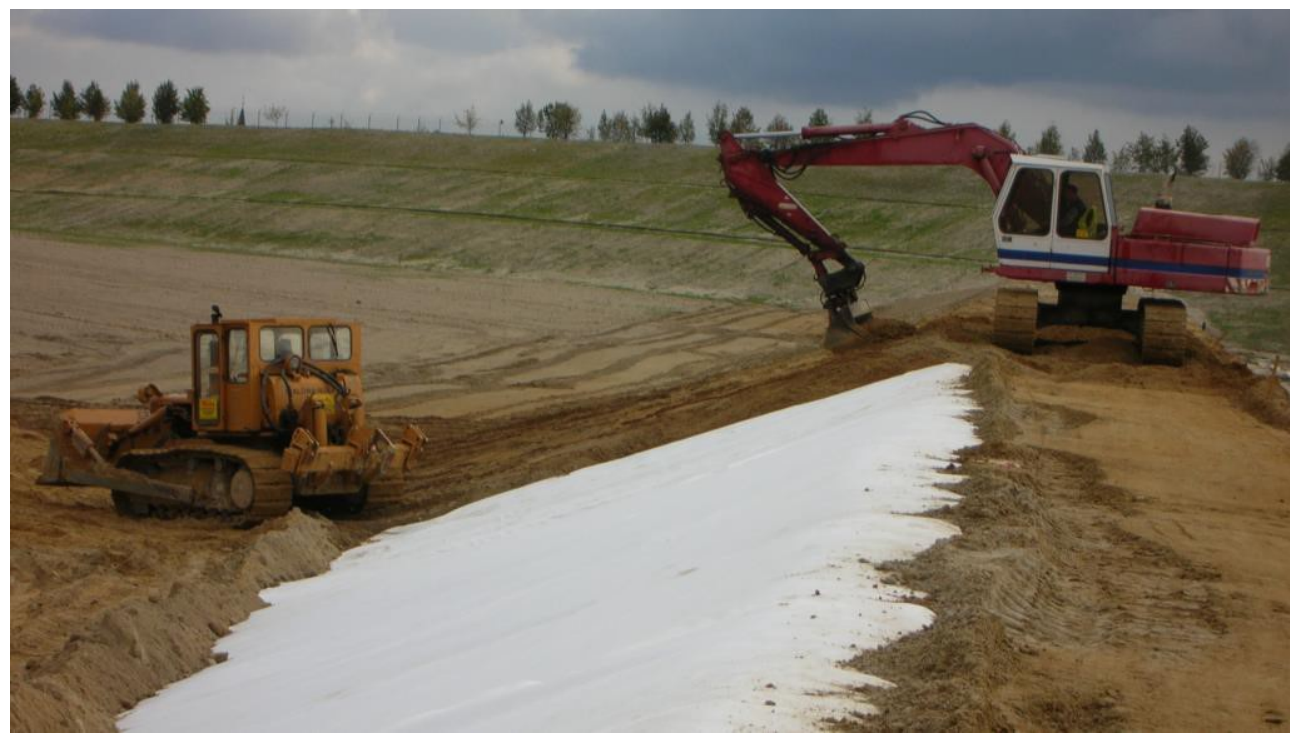

Fig. 10. Decomposition of the external protective layer above the geotextile - the water-isolating layers might have been damaged by e.g. a bulldozer blade or a scoop

What is more, during the first stage of waste disposal in Cell No. 2, despite the $50 \mathrm{~cm}$ thick protective layer of sand, the wheels (rollers) of the compactor armed with spikes ruptured its insulating layer in several places. Had it not been for the DSS warning system (here merely an additional electronic surveillance system), the traditional warning system described above involving typical drainage of clean waters and supplying water to piezometers arranged along the circumference of the cell crust (area: $16.57 \mathrm{ha}$ ) would have only indicated the presence of contaminants but it would not have been able to provide precise data on leak locations and the number of leaks. The DSS could do it accurately and did it, with an accuracy of $15 \mathrm{~cm}$, which ruled out random digging in previously compacted waste in search of leaks. However, not all of the waste storage cells built in an analogous period have similar safety systems in place, which renders them incapable of full control over the integrity of sealing layers. Despite the fact that waste disposal cells are earth structures that look massively, they are protected by materials having low resistance to point loads. In addition, the bottoms of the deep disposal landfills are susceptible to floating due to uplift pressure exerted by groundwater, they are also susceptible to flooding with waters coming from extensive precipitation and floodwaters, as is the case here. The paper touched upon only one of the topics related to the operation of environment protection facilities, such as waste landfills whose objective is to process, treat, and store waste by disposing of it. Nevertheless, their activity is not neutral to the environment and they can transform into sources of contamination themselves in some emergency situations.

\section{Conclusions}

Erection of any facility, regardless whether it is a building or another construction, does not finish the construction process which enters the most difficult stage of a full variable load. It is the 'actual' test of technical condition of each facility [11]. While test loads are applied in typical bridge structures and the condition of scratches and cracks in buildings is observed, this warning system will not be effective in such buildings as environmental protection facilities, including hazardous and non-hazardous waste landfills. 
difficult-to-reverse and progressing pollution of the environment, verging on an ecological disaster. Hence, in addition to generally applied and even proven warning systems, other security measures should be employed whenever possible to notify the user of a possible threat to the use safety of the facility and indicate its source. The paper describes one of such systems which - at the time of its implementation - was not widely known, yet it could demonstrate a possible (but unlikely, according to general opinion) unreliability of the cell protective membranes and consequences of the same. It was an unconventional solution. However, the practice shows it was very effective. Although such additional solutions (systems) have not been thoroughly proved in practice, they should be applied in protection systems not only for processing facilities of waste landfills, but wherever there might be any risk of environmental pollution by harmful substances, e.g. in technical solutions of sewage treatment plants, refineries, petrol stations, garages, workshops, production plants, car washes, boiler houses, cemeteries, etc. The simple system for sub-landfill monitoring described herein could successfully replace many complex and expensive systems. However, due to consequences of hazards posed by intensive and long-term operation of environmental protection facilities, such systems should be applied additionally, regardless of any other systems. The problem of safe operation of landfills is worldwide and no universal protection and monitoring methods, which could completely eliminate their negative influence on the environment, have been developed to date.

\section{References}

1. Rozporządzenie Ministra Środowiska z dnia 30 kwietnia 2013 r. w sprawie składowisk odpadów

2. Ustawa z dnia 7 lipca 1994 roku Prawo budowlane z późn. zmianami

3. Bilitewski B., Hardtle G., Klaus M. 2006. Podręcznik gospodarki odpadami, teoria i praktyka, Warszawa: Wydawnictwo Seidel - Przywecki Sp. Ss.200.

4. Korzeniowska-Rejmer E., Rola geotechniki w zapewnieniu bezpiecznego sktadowania odpadów komunalnych, Czasopismo Techniczne, z. 1-ŚS/2003, Wydawnictwo Politechniki Krakowskiej, Kraków 2003, 159-168.

5. Żygadło M., Gospodarka odpadami komunalnymi, Kielce 1998.

6. Stępniak S., Rozwiązania geotechniczne chroniace wody gruntowe pod wysypiskami, Gospodarka Wodna, 12/1994, 286-288.

7. Carbofol, Huls Troisdorf AG - materiały ofertowe firmy.

8. Koc-Jurczyk J., Treatment technologies of municipal waste landfill leachates, Sewages and Waste Materials in Environment, 2009, 59-71.

9. Davis J.S., Energy Limits to Technical Recycling, Conf. Papers „Conversion of Refuse

10. Laner D., Crest M., Scharff H., Morris J.W.F., Barlaz M.A., A review of approaches for the long-term management of municipal solid waste landfills, Waste Management, Vol. 32, 3/2012, 498-512.

11. Laner D., Fellner J., Brunner P., Future landfill emissions and the effect of final cover installation--a case study, doi.org/10.1016/j.wasman.2011.02.022.

12. Mulvey F., Environmental monitoring of landfills Environmental \& Earth Sciences and Wendi Trotter, Environmental \& Earth Sciences International 1999-2004

13. Ritzkowski M., Heyer KU., Stegmann R., Fundamental processes and implications during in situ aeration of old landfills, doi.org/10.1016/j.wasman.2005.11.009.

14. Slimak K., Environmental Health Perspectives, DOI:

10.1289/ehp.7827309. 